\title{
PERLUKAH BARAM DILEGALKAN?
}

\author{
Saputra Adiwijaya
}

\section{PENDAHULUAN}

Sebagai bangsa yang kaya beragam akan budaya, Indonesia mempunyai banyak hasil dari kebudayaan yang hingga saat ini mengalami tantangan global sehingga perlu dilestarikan, suatu saat bukan tidak mungkin satu persatu hasil dari kebudayaan itu hanya menjadi cerita dongeng di masa yang akan datang. Sebagaimana diketahui juga bahwa hasil kekayaan kebudayaan yang beranekaragam itu lahir dan terbentuk karena adanya usaha nenek moyang kita pada masa lampau dalam mengatur kehidupan dan beradaptasi dengan lingkungannya.

Salah satu hasil dari kebudayaan itu adalah minuman tradisional yang beralkohol (traditional alcoholic beverages), bermacam bahan baku menjadi ciri khas dari pembuatan minuman beralkohol ini, dan tergantung dari potensi-potensi alam yang ada di daerah masing-masing di Indonesia. Sebagai contoh misalnya daerah pesisir akan berbeda bahannya dengan yang ada di wilayah penghasil padi (pegunungan).

Bagi orang Dayak khususnya, tradisi meminum minuman tradisional beralkohol (traditional alcoholic beverages) bisa di katakan sebagai ciri khas dari sebuah acara, biasanya dalam tradisi upacara penyambutan tamu yang datang, upacara tiwah, dan lain sebagainya. Sajian minuman tradisional yang mengandung alkohol ini pasti ada di acara-acara tersebut. Berbagai istilah disematkan bagi minuman tradisional beralkohol ini misalnya baram, anding, atau juga ada menyebutnya arak atau juga tuak.

Pada bagian lainnya banyak filosofi yang menjadi semangat dalam pembuatan minuman tradisional beralkohol ini, dan ketika meminumnya pun tidak sembarangan, seperti yang disebutkan diatas ada acara-acara khusus yang menjadi bolehnya minuman tradisional ini. salah satu yang penulis ketahui misalnya bahwa tanda suksesnya sebuah keluarga dalam panen padi yang berlimpah maka baram seperti wajib dibuat oleh keluarga itu, jika panen tidak seberapa maka baram tidak akan dibuat.

\section{Baram; kondisinya sekarang}

Penulis berusaha tidak membahas tema tentang baram ini untuk menyentuh wilayah hukum agama (khususnya agama Islam) karena dalam tulisan ini akan berusaha menyajikan secara kajian budaya secara umum bahwa ada makna baram bagi orang Dayak, berikut potensi-potensi baram sebagai salah satu kekayaan hasil budaya suku dayak yang mempunyai nilai jual secara global, dan tantangannya ke depan.

Sebagai minuman tradisional beralkohol (traditional alcoholic beverages) baram merupakan minuman lokal suku dayak yang jika dilihat dari bahanbahannya merupakan campuran dari jahe, lengkuas, kunyit, akar alang-alang dan campuran lainnya sehingga jika diminum secara tidak berlebihan bisa dikatakan 
justru menyehatkan, memang pendapat ini perlu kajian lebih lanjut apakah kemudian jika diminum sesuai takaran menimbulkan efek sehat seperti apa, kemudian jika diminum secara berlebihan apakah keburukannya selain tentunya memabukan.

Efek memabukan ini kadang menjadi kontroversi karena dalam beberapa kasus, peminumnya, pedagang atau pembuat baram ditangkap dengan alasan tidak berizin (ilegal), mengganggu ketertiban umum, meresahkan masyarakat. Sementara pada bagian yang lain membeli minuman dari merek tertentu di tokotoko penjual minuman yang berizin (atau tidak) dianggap sebagai hal yang wajar karena yang dijual kadar alkoholnya tidak tinggi, apakah jika diminum dalam jumlah banyak juga memabukkan minuman merek tertentu itu? Kemudian bagaimana dengan misalnya penyalahgunaan pil zenith yang juga banyak beredar kemudian juga digunakan untuk mabuk-mabukan. Sepertinya perlu diskusi yang mendalam untuk menyepakati kata mabuk ini, sehingga ditemukan sebuah jalan tengah yang bisa menjadi kerangka acuan bagi pemerintah (daerah), peminum minuman yang dianggap memabukan, penjual minumannya, dan seluruh pihak yang mempunyai kepentingan dalam memahami permasalahan ini.

\section{Baram dan Pelestarian Budaya Dayak}

Meminum minuman tradisonal yang beralkohol bagi orang dayak sebenarnya bukan hal yang asing, apakah kemudian hal ini menimbulkan kemudian stretotipe bahwa orang dayak terkenal peminum ? pada bagian lain seluruh masyarakat yang tinggal di DAS di Kalimantan Tengah untuk minuman tradisional yang mengandung alkohol ini sejak zaman dulu terkenal sebagai pembuat minuman tradisional ini dengan berbagai macam ciri khasnya. Bahkan bisa dikatakan ada perbedaan dari bahan, cara pembuatan dan pengolahannya, dan rasanya hingga efek yang ditimbulkannya.

Ada filosofi bahwa baram yang dibuat biasanya sebagai tanda panen padi yang berhasil (berlimpah), apakah jika dihubungkan dengan kondisi sekarang ketika lahan bercocok tanam (padi) semakin tergerus oleh perkebunan semakin mengurangi pembuatan baram, perlu kajian mendalam lagi apakah ada hubungan antara semakin menipisnya lahan persawahan dengan tingkat baram yang diproduksi oleh pembuat baram. Sementara itu para pembuat baram juga sudah tidak menurunkan cara membuat baram ini kepada generasi mudanya, ini lah beberapa hal yang mungkin menjadi renungan bahwa baram bisa jadi sebagai minuman tradisional beralkohol yang hanya tinggal cerita.

Penulis pernah mendatangi salah satu Desa di Kabupaten Katingan tepatnya di Desa Tumbang Tanjung, disitu penulis sempat melakukan sedikit observasi tentang minuman tradisional beralkohol ini, ternyata yang membuat sudah tua dan bukan tidak mungkin ketika beliau sudah tidak ada maka yang menjadi penerusnya bisa tidak ada pula. Sementara itu untuk yang mengkonsumsinya biasanya pada saat ada upacara adat, sangat jarang untuk diminum sembarangan untuk mabuk-mabukan.

Menjadi hal yang prioritaskah ketika ada nilai budaya yang mulai hilang ini untuk dilestarikan? Pada bagian lain para pembuat, dan penjual baram ini ditangkap dengan alasan tidak berizin. Jika diberi izin apakah kemudian juga 
bebas menjualnya ? sementara para penjual yang berizin menjual produk-produk yang sebenarnya dari luar (Kalimantan Tengah) dengan alasan lebih higienis, sudah teruji BPOM, lebih bisa mengontrol peminumnya karena kandungan alkoholnya rendah dan berbagai macam argumen yang sebenarnya kesemuanya itu bisa didiskusikan lagi.

\section{Baram sebagai alternatif bagi pemberdayaan masyarakat}

Ketika arak Bali bisa dikemas dan mempunyai nilai jual tinggi, apakah kemudian baram bisa seperti itu ? atau orang Korea yang juga menamakan minumannya dengan baram yang dikemas dengan botol yang bagus dan dijual juga di Indonesa saat ini dengan merek Baram Korean Drink (Soju) ? jika kita lihat dari sisi kajian pemberdayaan hal ini bisa menjadi bahan diskusi yang menarik, bahwa pemberdayaan itu secara sederhana bisa dimaknai adanya sebuah kemandirian dari suatu individu atau sekelompok masyarakat agar mempunyai sebuah kekuatan (power) agar bisa mempunyai kapasitas dalam membangun dirinya sendiri atau kelompoknya untuk keluar dari ketidakberdayaan baik itu secara ekonomi, sosial, atau politik dan hukum.

Jika memang baram ingin dijadikan sebuah komoditi dan menghasilkan berbagai macam sentra kewirausahaan yang bisa menyerap tenaga kerja mandiri dan bisa meningkatkan pendapatan masyarakat kenapa tidak. Maka hal ini perlu berbagai kajian yang nantinya menjadi sebuah peraturan (daerah) yang menjadi acuan bagi semua pihak sebagai aturan main bagi masyarakat pembuat baram, dan juga mengkonsumsinya sehingga tidak ada lagi alasan-alasan yang (mungkin) selama ini dianggap merugikan masyarakat, terutama pembuat baram.

Berangkat dari hal tersebut maka yang dibenahi adalah: Pertama, melakukan pemetaan (mapping) pembuat baram yang ada di seluruh Kalimantan Tengah dengan menggandeng akademis (peneliti) sebagai sebuah kajian komprehensif, penulis yakin semua DAS yang ada di Kalimantan Tengah mempunyai potensi ini. Jika dipersempit lagi bisa dimulai dari kota Palangkaraya atau Kabupaten Katingan. Ketika hasil pemetaan (mapping) para pembuat baram ini sudah dihasilkan maka usulan yang diajukan didiskusikan ke dinas yang berwenang misalnya dinas perindustrian dan perdagangan, BPOM, dinas kesehatan, dinas pariwisata, DPRD, atau pejabat politik yang ada di tiap kabupaten/kota.

Kedua, memberikan pelatihan pengemasan dan pengawetan yang baik dan higienis kepada pembuat baram dengan menggandeng pihak BPOM dan dinas kesehatan. Hal ini penting karena akan menambah nilai jual suatu produk ketika dijual ke luar, jika perlu melakukan studi banding ke daerah pembuat minuman tradisional beralkohol (traditional alcoholic beverages) yang berhasil.

Ketiga, pemasaran. Pada bagian ini memang diperlukan peraturan daerah (perda) misalnya siapa saja yang boleh meminumnya, di mana boleh produk ini dijual, kandungan alkoholnya disesuaikan juga tentunya dan hal detil lainnya.

Keempat, selalu melakukan evaluasi. Evaluasi ini terkait dengan berbagai macam yang menjadi kelemahan ketika sebuah produk sudah dijual di pasaran. Misalnya apakah ada peningkatan pendapatan para pembuat baram, dampaknya 
kepada masyarakat ketika baram sudah beredar luas dari kajian sosial, hukum, dan kesehatan, tindakan aparat pemerintah jika ada yang melanggar. Namun demikian, keempat hal ini bukanlah hal yang mutlak, perlu diskusi yang tepat agar masalah ini menjadi lebih baik sehingga semua pihak bisa saling memberi solusi.

\section{PENUTUP}

Ada sebuah nilai budaya yang perlu dilestarikan, dan sebuah potensi pemberdayaan untuk masyarakat dari baram sebagai minuman tradisional beralkohol (traditional alcoholic beverages) khususnya bagi orang Dayak, namun apakah hal tersebut menjadi prioritas ditengah maraknya juga permasalahan sosial yang lainya termasuk tentunya korupsi. Mengurus dan mengelola sebuah pemerintahan (daerah) beserta warganya tidak hanya dari sekedar mengurus urusan baram, banyak hal-hal penting lainnya yang menjadi tugas semua pihak seperti aparat pemerintah sebagai pembuat kebijakan, akademisi (peneliti), dan masyarakat luas seluruhnya. Semoga dimasa yang akan datang wacana-wacana kecil ini bisa bermanfaat bagi semua pihak.

\section{DAFTAR PUSTAKA}

FOD. 2015. Filosofi Baram - Minuman Keras Khas Dayak Ngaju. https://folksofdayak.wordpress.com/2015/07/10/filosofi-baram-minumankeras-khas-dayak-ngaju/

Hikaru. 2011. Baram, Tuak Khas Kalimantan. https://hikarusky.wordpress.com/2011/10/15/baram-tuak-khas-kalimantan/ Mardikanto, Totok. Soebiato, Poerwoko. 2015. Pemberdayaan Masyarakat dalam Perspektif Kebijakan Publik. Alfabeta. Bandung

Suharto, Edi. 2009. Membangun Masyarakat Memberdayakan Masyarakat. PT Refika Aditama. Bandung.

Suparjan dan Hempri S. 2003. "Pengembangan Masyarakat dari Pembangunan Sampai Pemberdayaan,” CRS Indonesia, Yogyakarta. 